Borneo Journal of Phamascientech, Vol. 04, No. 01, April Tahun 2020

ISSN-Print. 2541-3651

ISSN-Online. 2548 - 3897

Research Article

\title{
GAMBARAN KEJADIAN EFEK SAMPING PADA PENGGUNAAN OBAT OFF LABEL PASIEN LUPUS
}

\section{DESCRIPTION OF SIDE EFFECTS ON THE USE OF MEDICINE OFF LUPUS PATIENT LABELS}

\author{
IwanYuwindry ${ }^{*}$, Noval \\ Universitas Sari Mulia \\ *iwanyuwindry@unism.ac.id
}

\begin{abstract}
ABSTRAK
Lupus Eritematosus Sistemik merupakan penyakit inflamasi autoimun kronis yang belum jelas penyebabnya, memiliki variasi gambaran klinis yang luas dan tampilan perjalanan penyakit yang beragam. Penggunaan obat-obatan off label seperti kortikosteroid untuk pengobatan SLE dapat mengakibatkan potensi efek samping yang besar terhadap pasien Lupus. Penelitianini bertujuan untuk mengetahui gambarankejadian efek samping pada penggunaan obat-obatan off label pasien lupus. Penelitian ini dilakukan menggunakan desain penelitian observasional deskriptif dengan carasurveymenggunakan intrumen Algoritma Naranjodengan responden pada penelitian ini berjumlah 28 responden. Berdasarkan penelitian yang dilakukan didapatkanhasil bahwaefek samping penggunaan obat-obatan off label menunjukkan sebanyak 12 responden atau 43\% mengalami klasifikasi Probable (kemungkinanbesarterjadi ROM. IO). Hasil ini menunjukkan bahwa penggunaan obat-obatan off label pada terapi lupus dapat memunculkan resiko kemungkinan besar terjadinya reaksi obat merugikan (ROM).
\end{abstract}

Kata Kunci: Lupus, Off Label, Efek Samping, Autoimun. 
Borneo Journal of Phamascientech, Vol. 04, No. 01, April Tahun 2020

ISSN-Print. 2541-3651

ISSN-Online. 2548 - 3897

Research Article

\begin{abstract}
Systemic lupus erythematosus is a chronic autoimmune inflammatory disease whose cause is not yet clear, has a wide variety of clinical features and diverse appearance of the disease course. The use of off label drugs such as corticosteroids for the treatment of SLE can result in a large potential side effect for Lupus patients. This study aims to determine the description of the occurrence of side effects on the use of drugs off lupus patients.This research was conducted using a descriptive observational research designby surveying using the Naranjo Algorithm instrument with 28 respondents. Based on research conducted, it was found that the side effects of using off label drugs showed that 12 respondents or $43 \%$ experienced Probable classification (most likely ROM. IO). These results indicate that the use of off-label drugs in lupus therapy can pose a risk of the possibility of adverse drug reactions.
\end{abstract}

Keywords: Lupus, Off Label, Side Effects, Autoimmune. 
Borneo Journal of Phamascientech, Vol. 04, No. 01, April Tahun 2020

ISSN-Print. 2541-3651

ISSN-Online. 2548 - 3897

Research Article

\section{PENDAHULUAN}

Sistemik Lupus Eritematosus (SLE) merupakan penyakit reumatik autoimun yang ditandai adanya inflamasi tersebar luas, yang mempengaruhi setiap organ atau sistem dalam tubuh. Penyakit ini berhubungan dengan deposisi autoantibodi dan kompleks imun sehingga mengakibatkan kerusakan jaringan (Isbagio, 2009).

Gejala-gejala konstitusional adalah demam, rasa lelah, lemah dan berkurangnya berat badan yang biasanya berat badan yang biasanya timbul pada masa awal penyakit dan dapat berulang dalam perjalanan penyakit ini. Keletihan dan rasa lemah bisa timbul sebagai gejala sekunder dari anemia ringan yang ditimbulkan oleh SLE.

Prevalensi penyakit lupus yang merupakan penyakit tidak menular saat ini terus meningkat. Data prevalensi di setiap negara berbeda-beda, dimana dalam suatu studi sistemik di Asia Pasifik memperlihatkan data insidensi sebesar 0,9 sampai dengan 3,1 per 100.000 populasi per tahun. Prevalensi kasar yaitu sebesar 4,3 sampai dengan 45,3 per 100.000 populasi. The Lupus Foundation of America memperkirakan sekitar 1,5 juta kasus terjadi di Amerika dan setidaknya terjadi lima juta kasus di dunia. Setiap tahun diperkirakan terjadi sekitar 16 ribu kasus baru Lupus. Organisasi Kesehatan Dunia atau WHO mencatat jumlah penderita penyakit Lupus di seluruh dunia dewasa ini mencapai lima juta orang. Sebagian besar dari penderita lupus adalah perempuan usia produktif dan setiap tahun ditemukan lebih dari 100 ribu penderita baru.

Masalah utama dalam penanganan terapi lupus yaitu sebagian besar obat yang masuk dalam guideline terapi yang dikeluarkan oleh Perhimpunan Rematologi Indonesia tahun 2014 belum mendapat persetujuan dari FDA atau BPOM sehingga masih dalam kategori obat off label untuk terapi SLE.Penggunaan obat-obatan off label seperti kortikosteroid dapat mengakibatkan potensi efek samping yang besar terhadap pasien Lupus seperti sakit kepala, kegelisahan, insomnia, ruam, dermatitis, perubahan pigmen kulit dan rambut, gangguana pencernaan dan ketoksikan okular.

Efek samping obat adalah reaksi yang tidak dikehendaki yang muncul saat 
Borneo Journal of Phamascientech, Vol. 04, No. 01, April Tahun 2020

ISSN-Print. 2541-3651

ISSN-Online. 2548 - 3897

Research Article

penggunaan klinik pada terapi suatu penyakit. Efek samping obat yang merugikan dapat menyebabkan pasien kehilangan kepercayaan terhadap dokter, sehingga mereka mencari pilihan pengobatan mandiri yang bisa menyebabkan efek samping obat lain. Sekitar 5\% dari semua pasien yang masuk rumah sakit merupakan akibat dari kejadian efek samping obat dan sekitar 10\%-20\% dari pasien rawat inap akan memilki minimal satu efek samping obat selama mereka tinggal di rumah sakit (Schatz, 2015).

Berdasarakan uaraian tersebut, maka peneliti ingin mengetahui tentang gambaran kejadian efek samping pada penggunaan obat-obatan off label pasien lupus. Penelitian ini bertujuan untuk mendapatkan data yang nyata terkait tingkat efek samping yang terjadi pada penggunaan obat off label pada terapi pasien lupus.

\section{METODOLOGI}

Penelitian ini menggunakan desain penelitian observasional deskriptif dengan menggunakan cara survey untuk melihat kejadian efek samping penggunaan obatobatan off label pada pasien lupus. Penelitian ini merupakan penelitian prospektif selama 3 bulandari 1 Juli2019 sampai 1 Oktober 2019, dengan mengobservasi pasien lupus serta menggunakan intrumen berupa Algoritma Naranjo untuk mengetahui efek samping yang terjadi pada terapi penyakit Lupus yang menggunakan obat-obatan off label. Penelitian ini dilakukan di bangsal Penyakit Dalam RSUD Ulin Banjarmasin dengan jumlah responden yang merupakan Orang dengan Lupus (Odapus) dan sedang melakukan pengobatan menggunakan obatobatan off label di Poli Penyakit Dalam RSUD Ulin Banjarmasin selama penelitian berjumlah 28 responden. Jumlah responden yang masuk dalam kriteria inklusi juga sama yaitu 28 responden.

Kriteria inklusi pada penelitian ini yaitu semua pasien Lupus di bangsal Penyakit Dalam RSUD Ulin Banjarmasin, pasien telah menjalani pengobatan Lupus dengan menggunakan obat-obat golongan kortikosteroid dan bersedia mengikuti penelitian. Kriteria ekslusi yang ditetapkan dalam penelitian ini, meliputi pasien dengan gangguan mental atau kendala bahasa yang dapat menggangu jalannya proses penelitian, pasien yang tidak 
Borneo Journal of Phamascientech, Vol. 04, No. 01, April Tahun 2020

ISSN-Print. 2541-3651

ISSN-Online. 2548 - 3897

Research Article

bersedia mengikuti penelitian dan mengundurkan diri selama mengikuti penelitian.

Tahapan pengambilan sampel dilakukan dengan mengedepankan ethical clearance, yaitu dengan meminta izin kepada responden dengan bukti tertulis berupa informed consent. Peneliti juga telah melalui uji ethical clearance di RSUD Ulin Banjarmasin dan dinyatakan lulus untuk melakukan penelitian.

Pada penelitian ini dilakukan analisis data univariat. Analisis univariat yang dilakukan pada penelitian ini untuk mengetahui gambaran pendidikan, usia, jenis kelamin dan pekerjaan serta gambaran kejadian efek samping pada penggunaan obat-obatan off label pasien lupus.

\section{HASIL DAN PEMBAHASAN}

Analisis univariat yang dilakukan pada penelitian ini untuk mengetahui gambaran karakteristik responden meliputi pendidikan, usia, jenis kelamin dan pekerjaan serta gambaran kejadian efek samping pada penggunaan obat-obatan off label pasien lupus.

\section{Hasil}

\section{Karakteristik Responden}

Karakteristik responden ini dapat dilihat langsung dari jawaban pada bagian data karakteristik kuesioner yang langsung dijawab oleh responden.

Tabell.Distribusi Frekuensi Berdasarkan Karakteristik Responden di Poli Penyakit Dalam RSUD Ulin Banjarmasin periode1 Juli - 1 Oktober 2019

\begin{tabular}{llcc}
\hline \multicolumn{2}{c}{ Karakteristik } & N & $\mathbf{( \% )}$ \\
\hline Pendidikan & SD & 0 & $0 \%$ \\
& SMP & 2 & $7 \%$ \\
& SMA & 6 & $21 \%$ \\
Usia & PerguruanTinggi & 20 & $72 \%$ \\
& Anak 5-11 Tahun & 0 & $0 \%$ \\
& Remaja 12-25 Tahun & 12 & $43 \%$ \\
& Dewasa 26-45 Tahun & 15 & $54 \%$ \\
JenisKelamin & Lansia 46-65 Tahun & 1 & $3 \%$ \\
Pekerjaan & Laki-Laki & 1 & $3 \%$ \\
& Perempuan & 27 & $97 \%$ \\
& PNS & 2 & $7 \%$ \\
& Swasta & 3 & $11 \%$ \\
& Lain-Lain & 23 & $82 \%$ \\
\hline \multirow{6}{*}{} & & &
\end{tabular}

Tabel di atas menunjukkan distribusi frekuensi berdasarkan karakteristik responden, diperoleh gambaran tingkat pendidikan terbanyak responden yaitu perguruan tinggi sebesar 20 responden atau $72 \%$. Gambaran hasil penelitian tentang karakteristik usia menunjukkan responden dengan usia dewasa antara 26-45 Tahun yang merupakan responden yang paling banyak dalam penelitian ini yaitu berjumlah 15 responden atau 54\%. Gambaran hasil 
Borneo Journal of Phamascientech, Vol. 04, No. 01, April Tahun 2020

ISSN-Print. 2541-3651

ISSN-Online. 2548 - 3897

Research Article

penelitian tentang karakteristik jenis kelamin, dimana responden dengan jenis kelamin perempuan yang paling banyak dalam penelitian ini yaitu sebanyak 27 responden atau 97\%. Gambaran hasil penelitian tentang karakteristik pekerjaan, dimana responden dengan pekerjaan bidang lain-lain merupakan pekerjaan yang paling banyak yaitu berjumlah 23 responden atau $82 \%$.

Gambaran Kejadian Efek Samping Pada

Penggunaan Obat-Obatan Off Label Pasien Lupus.

Penentuan pola efek samping penggunaan obat-obatan off label pada pasien Lupus dilakukan dengan cara melakukan skoring terhadap instrumen kuesioner algoritma Naranjo. Skoring pola efek samping penggunaan obat-obatan off label dilakukan berdasarkan ketetapan yang telah ditentukan pada sumber yang telah ada yang digunakan sebagai rujukan dalam penelitian ini.

Skoring tersebut dapat dikategorikan dalam empat tingkatan, yaitu nilai <1 didefinisikan tidak terjadi ROM/ IO, nilai 13 didefinisikan sebagai possible (kemungkinan terjadi $\mathrm{ROM} / \mathrm{IO}$ ), nilai 4-8

didefinisikan sebagai probable (kemungkinan besar terjadi ROM/ IO) dan nilai 9-13 didefinisikan sebagai definite (pasti terjadi ROM/ IO).

Tabel II. Hasil distribusi frekuensi efek samping penggunaan obat berdasarkan klasifikasi

\begin{tabular}{|c|c|c|c|}
\hline No & Klasifikasi & Frekuensi & $\%$ \\
\hline 1 & $\begin{array}{l}\text { Possible } \\
\text { (Kemungkinan terjadi } \\
\text { ROM/ IO) }\end{array}$ & 6 & $21 \%$ \\
\hline 2 & $\begin{array}{l}\text { Probable } \\
\text { (Kemungkinan besar } \\
\text { terjadi ROM. IO) }\end{array}$ & 12 & $43 \%$ \\
\hline 3 & $\begin{array}{l}\text { Definite (Pasti terjadi } \\
\text { ROM/ IO) }\end{array}$ & 5 & $18 \%$ \\
\hline 4 & Tidak terjadi RO/ IO & 5 & $18 \%$ \\
\hline
\end{tabular}

Tabel di atas dapat diketahui bahwa hasil tingkat efek samping penggunaan obatobatan off label dilihat dari 4 kategori, dimana kategori yang tebanyak adalah Probable (Kemungkinanbesarterjadi ROM/ IO) sebanyak 12 responden atau 43\%, Possible (Kemungkinanterjadi ROM/ IO) sebanyak 6 responden atau 21\%, Definite (Pasti terjadi ROM/ IO) sebanyak 5 responden atau 18\%, tidak terjadi ROM sebanyak 5 responden atau $18 \%$.

Tingkat efek samping penggunaan obatobatan off label juga dinilai berdasarkan masing-masing item pertanyaan yang ada pada kuesioner. Penilaian ini dilakukan untuk mengetahui seberapa banyak jumlah 
Borneo Journal of Phamascientech, Vol. 04, No. 01, April Tahun 2020

ISSN-Print. 2541-3651

ISSN-Online. 2548 - 3897

Research Article

responden yang mengalami efek samping dan tidak mengalami efek samping berdasarkan jawaban responden pada itemitem pertanyaan yang adadikuesioner. Hasil rata-rata responden memberikan jawaban yang bervariasi terkait kejadian efek samping yang mereka alami. Efek samping dilihat dari jawaban responden terhadap masing-masing item pertanyaan algoritma Naranjo tersebut dimana pada pertanyaan item 10 merupakan pertanyaan dengan jumlah responden yang mengaku terjadi efek samping dengan jumlah 19 responden yang menyatakan terjadi efek samping atau $68 \%$. Sedangkan kejadian efek samping yang paling sedikit terjadi yaitu pada item pertanyaan 5 dengan jumlah 23 responden yang menyatakan tidak terjadi efek samping atau $82 \%$.

\section{Pembahasan}

Pada penelitian ini data karakteristik responden diperoleh dari instrumen kuesioner dan juga wawancara terhadap responden. Data karakteristik responden mengambarkan heterogenenitas dari sampelsampel yang didapat. Data karakteristik responden menunjukkan hasil dari beberapa kategori seperti pendidikan, usia, jenis kelamin dan pekerjaan. Pada klasifikasi pendidikan didapatkan hasil bahwa pendidikan yang terbanyak pada responden penelitian ini yaitu berpendidikan perguruan tinggi. Pada klasifikasi usia didapatkan hasil bahwa usia yang terbanyak pada responden penelitian ini adalah usia dewasa yaitu berkisar 26-45 tahun. Hasil ini memang terkait dengan penyakit lupus yang diderita oleh responden. Penyakit SLE ini merupakan gangguan kompleks yang terutama menyerang pasien pada usia produktif. Dimana pada pasien dengan penyakit lupus memang sangat rentan untuk menyerang individu dengan usia produktif, namun sampai saat ini belum ada penjelasan yang pasti terkait penyebab usia produktif paling banyak terserang penyakit lupus. Pada klasifikasi jenis kelamin pada data karakteristik responden ini didapatkan hasil bahwa jenis kelamin yang terbanyak pada responden adalah perempuan. Hal ini tidak lepas dengan penyakit lupus yang diderita oleh responden. Jenis kelamin sangat erat hubungannya dengan salah satu faktor penyebab penyakit lupus yaitu hormonal, dimana faktor-faktor penyebab penyakit 
Borneo Journal of Phamascientech, Vol. 04, No. 01, April Tahun 2020

ISSN-Print. 2541-3651

ISSN-Online. 2548 - 3897

Research Article

lupus yaitu faktor genetik, imunologik dan hormonal serta lingkungan diduga juga berperan dalam perjalanan penyakit. Perempuan merupakan kelompok yang lebih sering terjangkit penyakit lupus disbanding laki-laki, hal ini dikarenakan ada kaitannya dengan aktivitas hormon dan sistem kekebalan tubuh, dimana perempuan mempunyai aktivitas hormon paling banyak dan system kekebalan tubuh laki-laki yang lebih kuat. Faktor hormon pada perempuan yang mempunyai hubungan dengan meningkatnya tingkat aktivitas penyakit pada SLE adalah hormon estrogen dan prolaktin (Alarcon, 2001). Penjelasan ini memang belum ada penelitian yang pasti, namun penjelasan tersebut menggambarkan secara umum faktor kelompok perempuan paling sering mengalami penyakit lupus. Data klasifikasi pekerjaan dikarakteristik responden didapatkan hasil bahwa pekerjaan terbanyak pada responden penelitian ini yaitu lain-lain. Lain-lain didefinisikan sebagai pekerjaan individu yang masih dalam tahap pendidikan seperti sekolah atau kuliah. Hal ini sesuai dengan data usia responden yang diperoleh pada penelitian ini, dimana usia terbanyak responden adalah
26-45 tahun, yang mana pada usia itu masih dimungkinkan individu dalam tahap menempuh pendidikan kuliah.

Pada data analisis pola efek samping penggunaan obat-obatan off label yang didapatkan dalam penelitian ini menunjukkan hasil bahwa sebanyak 12 responden atau $43 \%$ mengalami klasifikasi Probable (kemungkinanbesarterjadi ROM. IO). Hasil ini menunjukkan bahwa penggunaan obat-obatan off label pada terapi lupus dapat dimemunculkan resiko kemungkinan besar terjadinya reaksi obat merugikan (ROM). Reaksi obat merugikan (ROM) penggunaan obat-obatan off label pada terapi lupus dapat dilihat dari kejadian penumpukan lemak dipipi (moon face), kejadian terkena infeksi, kejadian masalah kulit dan kejadian pelemahan fungsi otot. Hal ini sangat tidak menguntungkan pasien lupus apabila dalam terapinya muncul kejadian-kejadian yang merugikan tersebut, karena pasien lupus pada dasarnya akan mengalami kondisi-kondisi klinis yang sudah menurunkan kemampuan aktivitas pasien. Pada awal kejadian SLE gambaran klinis yang paling sering adalah artritis atau atralgia, gangguan ini dapat ditemukan pada 
Borneo Journal of Phamascientech, Vol. 04, No. 01, April Tahun 2020

ISSN-Print. 2541-3651

ISSN-Online. 2548 - 3897

Research Article

sekitar $90 \%$ dari seluruh kasus, seringkali sebagai manifestasi awal. Sendi-sendi yang paling sering terserang adalah sendi-sendi proksimal tangan, pergelangan kaki. Poliartritis SLE berbeda dari rematoid karena jarang bersifat erosif atau menimbulkan deformitas. Nodula subkutan juga jarang ditemukan pada penyakit SLE (Prince, 2010). Gejala-gejala konstitusional adalah demam, rasa lelah, lemah dan berkurangnya berat badan yang biasanya berat badan yang biasanya timbul pada masa awal penyakit dan dapat berulang dalam perjalanan penyakit ini. Keletihan dan rasa lemah bisa timbul sebagai gejala sekunder dari anemia ringan yang ditimbulkan oleh SLE. Manifestasi kulit mencakup ruam eritematosa yang dapat timbul pada pipi, leher dan anggota gerak atau seluruh tubuh. Kira-kira 40\% dari penderita SLE memiliki ruam khas berbentuk kupu-kupu. Kira-kira $65 \%$ dari penderita SLE akan mengalami gangguan pada ginjalnya, namun hanya $25 \%$ yang menjadi berat (Prince, 2010). Gambaran klinis yang ditimbulkan oleh penyakit tersebut tidak dapat dilakukan modifikasi lagi, sehingga apabila kejadian reaksi obat merugikan (ROM) yang kemungkinan besar dapat terjadi karena menggunakan obat-obatan off label, maka hal tersebut akan menambah buruk gambaran klinis yang ditimbulkan pada pasien lupus.

\section{KESIMPULAN}

Efek samping penggunaan obat-obatan off label yang didapatkan dalam penelitian ini menunjukkan hasil bahwa sebanyak 12 responden atau $43 \%$ mengalami klasifikasi Probable (kemungkinanbesarterjadi ROM. IO). Hasil ini menunjukkan bahwa penggunaan obat-obatan off label pada terapi lupus dapat memunculkan resiko kemungkinan besar terjadinya reaksi obat merugikan (ROM).

\section{DAFTAR PUSTAKA}

Alarcon. 2001.Systemic lupus erythematosus in three ethnic groups. IX. Differences in damage accrual. The University of Alabama. Birmingham: NCBI.

Aringer. 2012. Innate immune processes in lupus erythematosus.Division of Rheumatology.Department of Medicine III, University Clinical Center CarlGustavCarus. Dresden: NCBI.

Dworkin. 2010. Recommendations for the 
Borneo Journal of Phamascientech, Vol. 04, No. 01, April Tahun 2020

ISSN-Print. 2541-3651

ISSN-Online. 2548 - 3897

Research Article

Pharmacological Management of Neuropathic Pain: An Overview and Literature Update. Department of Anesthesiology, University of Rochester School of Medicine and Dentistry. New York: NCBI.

Isbagio H. 2009. Lupus Eritematosus Sistemik Dalam: Sudoyo AW, Setiyohadi B, Alwi I, et al, editor. Ilmu Penyakit Dalam Jilid III. Edisi kelima. Jakarta: Interna Publishing, 2565-2579.

Jennifer. 2010. Buku Ajar Patofisiologi. Jakarta: EGC.

Lin. 2006. The Effect of Brand Image and Product Knowledge on Purchase Intention Moderated by Price Discount. Journal of International Management Studies.

Lopez SJ, Snyder CR, Pedrotti JT. 2003. Hope: Many Definitions, Many Measures. Dalam S. J. Lopez \& C. R. Snyder (Eds).Positive Psychological Assessment, A Handbook of Models and Measures.Washington, DC, US: American Psychological Association 91-106.

Prince M. 2010. Histochemical and biochemical studies of parasite host interaction of Cassytha filiformis Linn and Zisyphus jujube Lamk. Current Science.

Priyanto, Duwi.2010. Teknik Mudah dan Cepat Melakukan Analisis Data Penelitian dengan SPSS. Yogyakarta: Gava Media.

Qureshi. 2011. Effect of silicon level on growth and yield of wheat in silty loam soil. Pak J Bot.

Santoso.2005.

MetodologiPenelitianKuantitatfdanKu alitatif. Jakarta: PrestasiPustaka.

Schatz. 2015. Managing asthma exacerbations in the emergency departement. Proc Am Thorac.

Shah. 2007. Pharmacognosy Review. Gujarat, India.

Stafford, L. 2008. Maintenance Strategies and romantic relationship type, gender and relational characteristics. Journal of Social and Personal Relationships.

Sugiyono. 2002. Metode Penelitian Administrasi. Bandung: CV Alfabeta. 